\title{
ENHANCEMENT OF THE HEAT TRANSFER OF THE DRY COOLING SYSTEM USING ROTATING RADIATOR
}

\author{
C. UMA MAHESWARI ${ }^{* 1}$, R. MEENAKSHI REDDY ${ }^{2} \&$ K. HEMACHANDRA REDDY ${ }^{3}$ \\ ${ }^{I}$ Research Scholar, Department of Mechanical Engineering, Jawaharlal Nehru Technological University, Anantapuramu, \\ Andhra Pradesh, India \\ ${ }^{2}$ Department of Mechanical Engineering, G. Pulla Reddy Engineering College, Kurnool, Andhra Pradesh, India \\ ${ }^{3}$ Chairman, Andhra Pradesh State Council of Higher Education, Andhra Pradesh, India
}

\begin{abstract}
The dry cooling system is one of the effective techniques to save water in the thermal power plants as water is getting a scarcer nowadays. The loss of water through evaporation can be controlled in the dry cooling method. To enhance the efficiency of the dry cooling system, more research is done. Radiators are one of the heat exchangers used in the automobiles which cools more effectively with less wastage or loss of coolant i.e. water. This paper explains the use of radiator to enhance the efficiency of the cooling system to cool the water experimentally. The radiator is rotated at a particular speed to get forced air by replacing the fan. The coolant from the heat source is supplied to the rotating radiators which get cooled faster due to the pressure drop. The loss of water is very negligible and efficiency is more than the dry cooling system.

KEYWORDS: Rotating Radiator, Dry cooling system, Heat exchanger, Energy, Temperature \& Heat transfer
\end{abstract}

Received: Mar 30, 2020; Accepted: Apr 20, 2020; Published: May 22, 2020; Paper Id.: IJMPERDJUN202062

\section{INTRODUCTION}

Water is the basic main resource for most of the industries. But water is scarcely available in many areas. Heat exchangers play the main role in exchanging heat from the heat source to the atmosphere. Dry cooling towers are one of the heat exchangers used in the thermal power plants which can reduce water evaporation and save water which is an utmost requirement in the eco-friendly environment. Radiators are another heat exchanger which removes heat with very less water evaporation. Nowadays radiators are attached to the dry cooling towers to improve the efficiency of the heat exchange.

Physical-mathematical model was developed to describe the thermo-flow characteristics of a large scale dry cooling system and optimized the design for safe operation [1]. The performance of the air cooling tower can be improved by using the optimal design with rotating wind deflectors [2]. A 3D Numerical model for Natural Draft Dry Cooling Towers (NDDCT) with vertical two-pass column radiators was performed with deviation in inflow air direction [3]. The effect of crosswind on transient startup was analyzed on (NDDCT) by theoretical approximation and numerical computations and validated with the experimentation and guaranteed a better performance with the cooperation of photo voltaic and concentrated solar thermal power plants in hybrid power generations [4]. A detailed investigation of heat \& mass transfer and aerodynamics for middle size power plants and reviewed different types of cooling towers [5]. An experimental study of an air-cooled condenser with three pass steam circulation with dry cooling system increases the thermal efficiency and resistance to the formation of ice [6]. The 
performance of an indirect dry cooling system can be improved by optimizing the flow of circulating water by using an entransy dissipation-based optimization method [7]. A computational model was developed by coupling the energy balances between circulating water and exhausts steam and investigated the flow and heat transfer of cooling air which performed better due to the interior and exterior windbreaker configurations [8]. Investigation showed that when the temperature and inlet air velocity is higher, thus, start-up is found to be faster [9]. A 3D CFD model was simulated and investigated the effect of wind deflectors to study the airflow and heat transfer in an indirect air cooling tower with aluminium exchanged surface condenser [10].

The objective of this paper is to improve the performance of a dry cooling tower using rotating radiators and to avoid the usage of fans. The heat exchanger used is an automobile radiator which gives better performance and less water evaporation [11]. Anti-freezing liquids or Nano fluids also can be used for better performance. The coolants used here can be recirculated at a faster rate and reduce the evaporation rate. The study of radiators shows that the weight, thickness of the radiator is reduced for convenience [12]. The performance of the working fluid for a particular application of the radiator was selected based on the Reynolds number and the pumping power [13]. The radiator tubes material was considered to non-hazardous, non-pollutant when scrap accumulation creates the problem [14]. The effect of multiple posts on the structural patch with variable geometry of rectangular and circular was investigated and found that a circular patch was found to be more effective [15]. The water is distributed in the radiator in a balanced way by dimensioning the pipes and the control valves to make the temperature distribution more efficient [16].The radiator is designed with the attenuation rate in the narrow beams which leads to reduce the wall losses and power handling capacity [17]. The design of the radiator was done to have more durable, cheap and provides higher cooling. The optimization of the radiator design is done to maximize the cooling potential with the parameters such as length, hydraulic pump specification [18]. The fuel consumption of the automobile can be decreased by reducing the weight of the radiator and it is made very compact to increase the lifetime of the radiator parts and provide the cooling more effectively [19]. The level of conduction between cooling tubes and fins plays the main role in the efficiency of the radiator. The best design is obtained by selecting the optimized louver angle, length and number of fins [20]. The heat transfer and pressure drop increases as the grooves count increases in the flat tube radiator [21].

\section{THEORETICAL ANALYSIS}

Compared to different types of cooling towers, dry cooling towers plays the main role to cool and maintain the required temperature of hot water expelled out of the thermal power plants with less evaporative loss of water which is the main objective in a water scarcity areas. The objective of this paper is to use the radiator as the heat exchanger in the dry cooling towers to avoid water loss. The size of the radiators is considered and optimization is done for different sizes. Design parameters used for calculating the temperature distribution of coolant in the radiator are followed as follows:

\subsection{Design of Fin}

Corrected fin length: $\quad \mathrm{L}_{\mathrm{c}}=\mathrm{L}_{\mathrm{f}}+\left(\mathrm{H}_{\mathrm{f}} / 2\right)$

Coefficient for calculating efficiency: $m=\left(\left(2 \times h_{a}\right) /\left(\mathrm{K} \mathrm{x} \mathrm{H}_{\mathrm{f}}\right)\right)^{1 / 2}$

Efficiency: $\eta_{\mathrm{f}}=\left(\tanh \left(m \times L_{c}\right)\right) /\left(m \times L_{c}\right)$

Surface area: $A_{f}=2 \times W_{f} \times L_{c}$ 
Base surface area: $A_{b}=\left(2 \times \operatorname{Lr} \times W_{t}\right)-\left(H_{f} x W_{f} \times N_{f}\right)$

Total surface area: $\quad \mathrm{Af}_{\text {inbase }}=\left(\mathrm{N}_{\mathrm{f}} \mathrm{X} \mathrm{A}_{\mathrm{f}}\right)+\mathrm{A}_{\mathrm{b}}$

Overall efficiency $=\eta_{\text {over }}=1-\left(\left(\left(N_{\mathrm{f}} \mathrm{x} \mathrm{A}_{\mathrm{f}}\right) /\left(\mathrm{A}_{\text {finbase }}\right)\right) \times\left(1-\eta_{\mathrm{f}}\right)\right)$

\subsection{Design of Tube}

Coolant Flow area of tube inner diameter $F_{a}=\left((\pi / 4) \times\left(D_{i}\right)^{2}\right.$

Total internal surface area: $A_{\text {in }}=2 \times \pi \times L_{r} \times N_{t}$

Total external surface area $A_{\text {ex }}=A_{\text {finbase }} \times N_{t}$

\subsection{Heat Rejection Calculations}

Velocity: $V=\left(\mathrm{m} /\left(\rho \times F_{a}\right)\right)$

Reynolds number: $\operatorname{Re}=\left(\left(\rho \times \mathrm{V}_{\mathrm{i}}\right) / \mu\right)$

Nusselt number: $\mathrm{Nu}=0.023 \times\left((\mathrm{Re})^{0.8}\right) \times\left((\mathrm{PR})^{0.3}\right)$

Convective heat transfer coefficient: $h=(\mathrm{Nu} \times \mathrm{K}) /\left(\mathrm{D}_{\mathrm{i}}\right)$

Overall heat transfer coefficient: $\mathrm{UA}=1 /\left(\left(1 /\left(\eta_{\mathrm{over}} \mathrm{xh}_{\mathrm{a}} \mathrm{x} \mathrm{A}_{\mathrm{ex}}\right)\right)+\left(1 /\left(\mathrm{h}_{\mathrm{w}} \mathrm{x} \mathrm{A}_{\mathrm{in}}\right)\right)\right)$

Number of transfer units: $\mathrm{NTU}=\left(\mathrm{UA} / \mathrm{C}_{\min }\right)$

Effectiveness $=\exp \left(\left(\left(\mathrm{NTU}^{0.22}\right) / \mathrm{Cr}\right) \times\left(\exp \left(-\mathrm{Cr} \times \mathrm{NTU}^{0.78}\right)-1\right)\right)$

$\mathrm{q}_{\max }=\mathrm{C}_{\min } \mathrm{x}\left(\mathrm{T}_{\mathrm{w}, \mathrm{in}^{-}}-\mathrm{T}_{\mathrm{a}, \text { in }}\right)$

Predicted heat transfer rate is obtained by $=($ effectiveness $) \times \mathrm{q}_{\max }$

\section{Outlet Temperatures}

Water outlet temperature: $\mathrm{T}_{\mathrm{w}, \mathrm{in}}-\left(\mathrm{q}_{\text {predicted }} / \mathrm{C}_{\max }\right)$

Air outlet temperature: $\mathrm{T}_{\mathrm{a}, \text { in }}+\left(\mathrm{q}_{\text {predicted }} / \mathrm{C}_{\mathrm{min}}\right)$

Table 1: Input Parameter

\begin{tabular}{|c|c|}
\hline Parameters & Units \\
\hline The inner diameter of the tube, $\mathrm{D}_{\mathrm{o}}$ & $\mathrm{m}$ \\
\hline The outer diameter of the tube, $\mathrm{D}_{\mathrm{i}}$ & $\mathrm{m}$ \\
\hline Length of the tube, $\mathrm{L}_{\mathrm{t}}$ & $\mathrm{m}$ \\
\hline Width of the tube, $\mathrm{W}_{\mathrm{t}}$ & $\mathrm{m}$ \\
\hline Height of tube, $\mathrm{H}_{\mathrm{t}}$ & $\mathrm{m}$ \\
\hline Number of tubes, $\mathrm{N}_{t}$ & \\
\hline Width of the radiator, $\mathrm{D}_{\mathrm{f}}$ & $\mathrm{m}$ \\
\hline The density of coolant, $\rho_{w}$ & $\mathrm{Kg} / \mathrm{m}^{3}$ \\
\hline The density of air, $\rho_{\mathrm{a}}$ & $\mathrm{Kg} / \mathrm{m}^{3}$ \\
\hline Dynamic viscosity, $\mu_{\mathrm{w}}$ & $\mathrm{Kg} /(\mathrm{m} . \mathrm{sec})$ \\
\hline Thermal conductivity of aluminium, $\mathrm{K}_{\mathrm{al}}$ & $\mathrm{W} / \mathrm{mK}$ \\
\hline Thermal conductivity of water, $\mathrm{K}_{\mathrm{w}}$ & $\mathrm{W} / \mathrm{mK}$ \\
\hline Thermal conductivity of air, $\mathrm{K}_{\mathrm{a}}$ & $\mathrm{W} / \mathrm{mK}$ \\
\hline Width of the fin, $\mathrm{W}_{\mathrm{f}}$ & $\mathrm{m}$ \\
\hline Height of fin, $\mathrm{H}_{\mathrm{f}}$ & $\mathrm{m}$ \\
\hline Number of fins, $\mathrm{N}_{\mathrm{f}}$ & \\
\hline Prandtl number of water, $\operatorname{Pr}_{\mathrm{w}}$ & \\
\hline Water inlet temperature $T_{\mathrm{w}, \text { out }}$ & ${ }^{\circ} \mathrm{C}$ \\
\hline
\end{tabular}


The equations of heat transfer were calculated using MATLAB coding. Table 1 shows the input parameters loaded for the theoretical calculations. Table 2 shows the output parameters obtained from the MATLAB coding.

Table 2: The Output Data

\begin{tabular}{|l|l|}
\hline \multicolumn{1}{|c|}{ Parameters } & \multicolumn{1}{|c|}{ Units } \\
\hline The mass flow rate of air, $\mathrm{m}_{\mathrm{a}}$ & $\mathrm{Kg} / \mathrm{sec}$ \\
\hline Velocity air, $\mathrm{V}_{\mathrm{a}}$ & $\mathrm{m} / \mathrm{s}$ \\
\hline Reynolds number for air, $\mathrm{Re}_{\mathrm{a}}$ & \\
\hline Nusselt number for air, $\mathrm{Nu}_{\mathrm{a}}$ & \\
\hline Convective heat transfer coefficient of air, $\mathrm{h}_{\mathrm{a}}$ & $\mathrm{Watt} / \mathrm{m}^{2} \mathrm{~K}$ \\
\hline Corrected fin length, $\mathrm{L}_{\mathrm{c}}$ & $\mathrm{m}$ \\
\hline Fin efficiency, $\mathrm{n}_{\mathrm{f}}$ & \\
\hline Area of the fin, $\mathrm{A}_{\mathrm{f}}$ & $\mathrm{m}^{2}$ \\
\hline Overall efficiency, $\mathrm{\eta}_{\mathrm{over}}$ & \\
\hline Internal area, $\mathrm{A}_{\mathrm{in}}$ & $\mathrm{m}^{2}$ \\
\hline External area, $\mathrm{A}_{\mathrm{ex}}$ & $\mathrm{m}$ \\
\hline The mass flow rate of coolant, $\mathrm{m}_{\mathrm{w}}$ & $\mathrm{Kg} / \mathrm{sec}$ \\
\hline Water velocity, $\mathrm{V}_{\mathrm{w}}$ & $\mathrm{m} / \mathrm{sec}$ \\
\hline Reynolds number, Re & \\
\hline Nusselt number for water, $(\mathrm{Nu})$ & \\
\hline convective heat transfer coefficient of water, $\mathrm{h}_{\mathrm{w},}$ & $\mathrm{Watt} / \mathrm{m}^{2} \mathrm{~K}$ \\
\hline overall heat transfer coefficient, $\mathrm{UA}$ & $\mathrm{Watt} / \mathrm{m}^{2} \mathrm{~K}$ \\
\hline Number of transfer units, $\mathrm{NTU}$ & -- \\
\hline Maximum heat transfer rate, $\mathrm{q}_{\text {max }}$ & $\mathrm{watts}$ \\
\hline Predicted heat transfer rate, $\mathrm{q}_{\mathrm{predicted}}$ & $\mathrm{watts}$ \\
\hline Water outlet temperature for the cylindrical tube, $\mathrm{T}_{\mathrm{w}, \text { out }}$ & ${ }^{\circ} \mathrm{C}$ \\
\hline
\end{tabular}

\section{OPTIMIZATION OF DESIGN}

The design parameters are optimized by varying factors such as tube length, width, height, number of tubes, number of fins, air velocity, the mass flow rate of air and coolant using Taguchi method in Minitab 16 software. Taguchi Orthogonal Array Design was selected with Columns of L27 (3 x 10) Array. The varied parameters are listed in Table 3.

Table 3: Parameters Varied for Optimization

\begin{tabular}{|l|l|l|l|l|}
\hline Cell & \multicolumn{1}{|c|}{ Parameters } & \multicolumn{3}{c|}{ Values varied } \\
\hline 1 & Width of tube $(\mathrm{m})$ & 0.02 & 0.04 & 0.06 \\
\hline 2 & Height of tube $(\mathrm{m})$ & 0.001 & 0.002 & 0.003 \\
\hline 3 & Width of fin $(\mathrm{m})$ & 0.02 & 0.03 & 0.04 \\
\hline 4 & Height of fin $(\mathrm{m})$ & 0.012 & 0.015 & 0.018 \\
\hline 5 & Number of tubes & 30 & 40 & 50 \\
\hline 6 & Number of fins & 400 & 500 & 600 \\
\hline 7 & Air mass flow rate $(\mathrm{kg} / \mathrm{s})$ & 1 & 5 & 10 \\
\hline 8 & Water mass flow rate $(\mathrm{kg} / \mathrm{s})$ & 1 & 5 & 10 \\
\hline 9 & Air velocity $(\mathrm{m} / \mathrm{s})$ & 15 & 20 & 25 \\
\hline
\end{tabular}

These parameters are loaded in Minitab and the array of L27 rows of data is obtained which are entered in MATLAB coding to get the final water outlet temperature. Taguchi analysis was done for all the input data and optimized for the nominal water outlet temperature. The nominal best value is presented for all the factors. From the previous paper 'Analysis of Design Parameters of Radiator'[11] it is observed that compared to other parameters the width of the fin, number of tubes and air velocity plays a major role in heat transfer rate and found that as the width of the fin, number of tubes and air velocity increases the heat transfer rate increases. 


\section{EXPERIMENTAL ANALYSIS}

This experimental set up was considered to cool the hot water delivered from a $1 \mathrm{MW}$ diesel Generator which is used as a power generator. Figure 1 represents the schematic diagram of the experimental setup and Figure 2 shows the photograph of the set up constructed. It consists of two radiators placed at the two ends of the radiator support frame for balancing during rotation. The radiators are downflow type flattened tubes are used. Aluminium tubes and aluminium fins are selected for effective heat transfer. The pressure cap is used for maintaining the pressure drop for increasing the heat transfer rate. If the radiators are to be used for higher capacity more than $5 \mathrm{MW}$ copper tubes and aluminium fins are recommended. The radiators are rotated with the help of electric motor $1.5 \mathrm{HP}$ with the gearbox and 3 stepped pulley assembly. The speeds of the rotating shaft can be varied by changing the belt position in the stepped pulley. The hot water from the heat source is pumped through the foot valve and sent to the radiator which is rotating. The digital tachometer was used to measure the rotating speed of the shaft. Digital thermocouples of T-type copper constantan were used to measure the inlet temperature in the water tank and the outlet temperature of the cooled water collected from the radiator. The water mass flow rate is controlled by operating the pressure valve and the flow rate can be measured by the rotameter of 015L/min capacity. The experiment was done by heating the water with an electric rod heater of capacity 0 to $6 \mathrm{KW}$. The ambient air temperature and air velocity were measured. The radiators used are downflow with tubes and fins materials as aluminium and copper respectively. The specifications of the radiators are taken from the optimized values of the 'Analysis of Design Parameters of Radiator' [11]. The experiments were conducted by varying the water mass flow rate, speed of rotating radiator shaft and inlet hot water temperature.

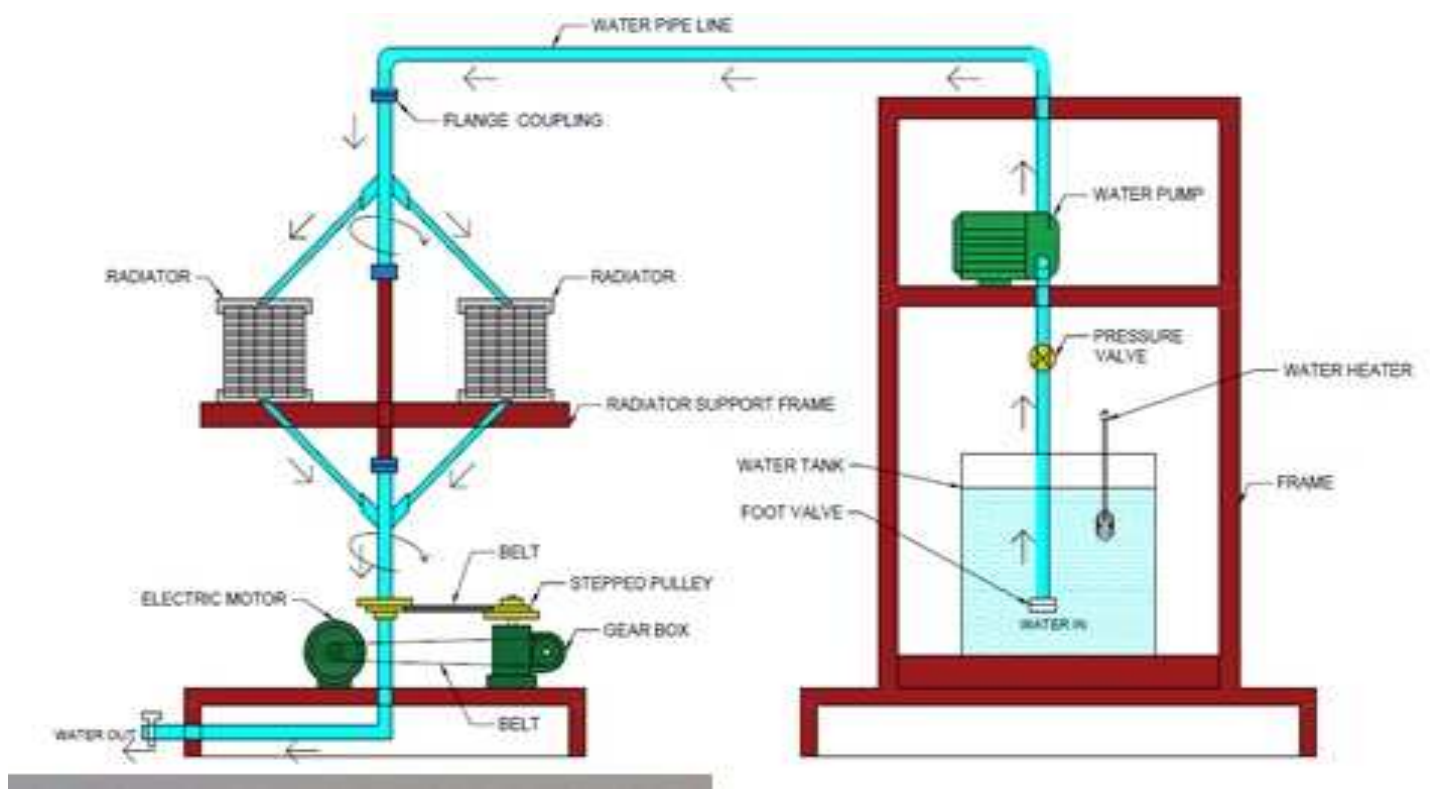

Figure 1: Schematic Diagram of the Experimental Setup

The ambient air temperature was $40^{\circ} \mathrm{C}$, the inlet water temperature was varied as 90,80 and $70^{\circ} \mathrm{C}$. The water mass flow rate considered was 1,5 and $10 \mathrm{~kg} / \mathrm{s}$. The speed of the rotating shaft is controlled to produce the opposing air velocity of 15,20 and $25 \mathrm{~m} / \mathrm{s}$. 


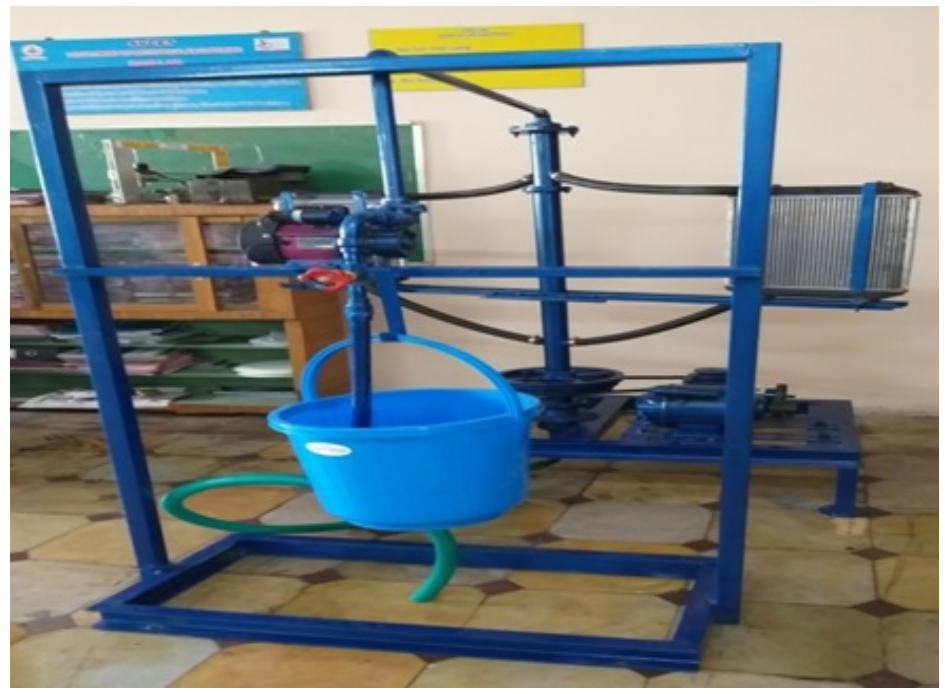

Figure 2: Photograph of the Experimental Setup

\section{RESULTS AND DISCUSSIONS}

The experimental investigation was studied by varying the inlet water temperature, the mass flow rate of water and the rotating speed of the shaft. Three different parameters are varied with 3 values and displayed in Figure 3. The results show that as the water mass flow rate increases, the water outlet temperature increases, and as the speed of rotating shaft increases, the water outlet temperature decreases. Hence it is proved that to obtain better efficiency of getting more heat transfer rate, the water mass flow rate should be decreased and shaft speed should be increased. The results were analyzed and compared with a $1 \mathrm{MW}$ diesel engine dry cooling tower commercially available in the industrial markets.

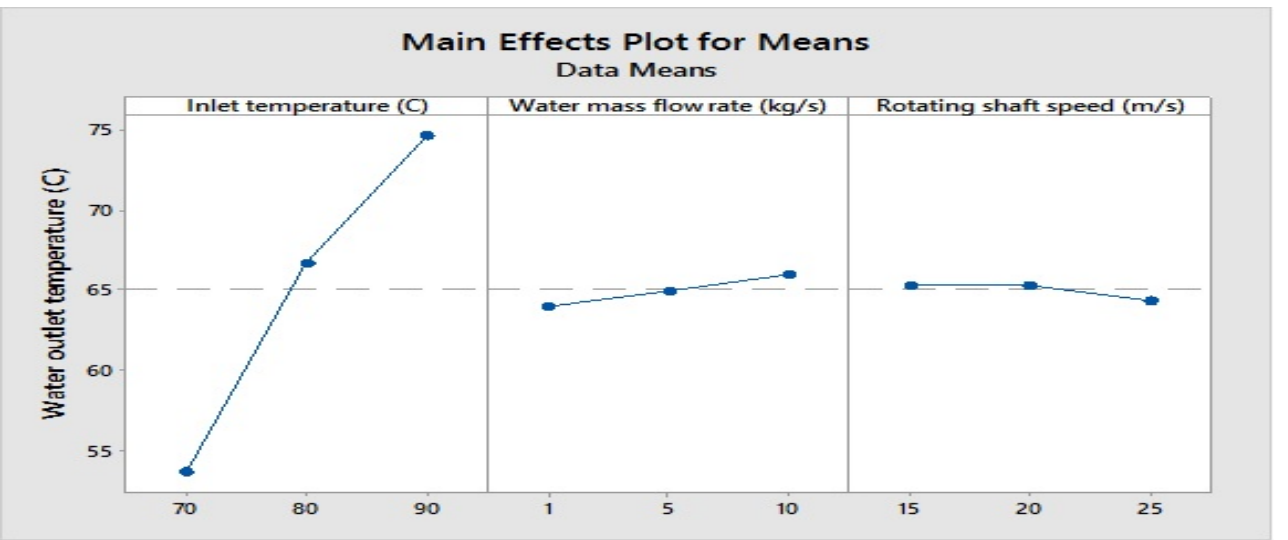

Figure 3: Graphical Response of Water Outlet Temperature with Varying the Input Parameters

At $40^{\circ} \mathrm{C}$ ambient air temperature, $10 \mathrm{~kg} / \mathrm{s}$ water mass flow rate and air velocity of $20 \mathrm{~m} / \mathrm{s}$, the water inlet temperature are varied for both dry cooling tower and rotating radiator. Figure 4 shows the water outlet temperature of both the cooling system and found that the radiator has more efficient compared to the commercially manufactured dry cooling tower. The water loss is $2 \%$ in the dry cooling system due to spillage, drift, blowdown and evaporation. But the water loss in the radiator is very negligible. The outlet temperature of the rotating radiator was compared with the dry cooling tower and found that rotating radiator is more effective than the dry cooling tower. Pressure drop plays a very important role in big radiators. The heat transfer rate increases due to the pressure drop [22]. Thus, the outlet water temperature gets decreased more with the pressure drop in the rotating radiator. The mass flow of water is shared by the number of radiators 
i.e. two in this experimental study and the air mass flow rate is increased due to sharing by heat exchangers. The capacity and number of motors required is also reduced in this setup as fan motors are required in dry cooling tower but motor is required to rotate the shaft only. The electric power required to run the fan is also reduced due to the reduction of forced fan motors.

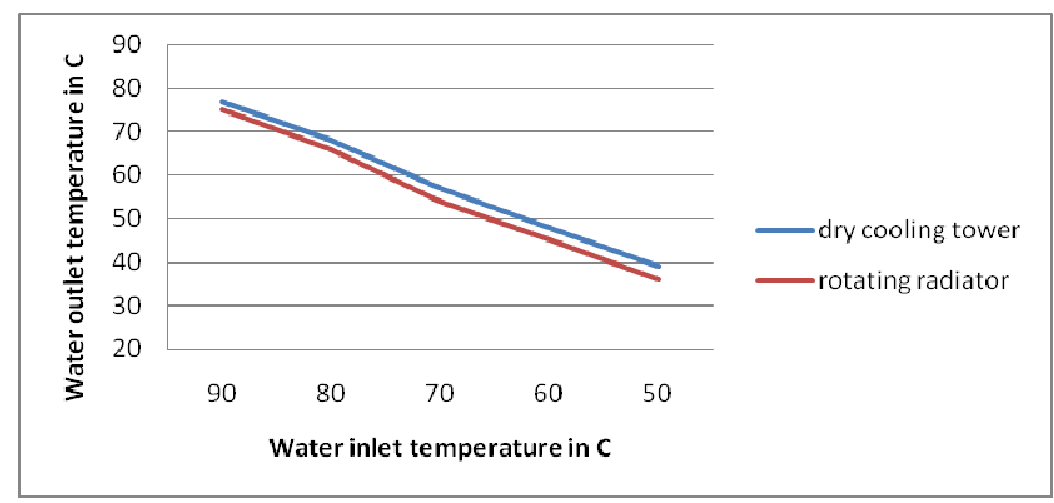

Figure 4: Comparison of Water Outlet Temperature

\section{CONCLUSIONS}

From the above theoretical analysis and optimization, the best size of the radiator was designed and required input parameters are considered to obtain the water outlet temperature. An experimental investigation was done to compare the water outlet temperature of the rotating radiator with the dry cooling tower that is available commercially in the industries. Compared to usual dry cooling towers used in industries, the rotating radiator gives a better efficiency as the water outlet temperature is decreased. As a result, it was found that the water loss is controlled and the efficiency is also improved.

\section{REFERENCES}

1. Xinming Xi, Lei Yang, Yanan He, Lijun Yang, Xiaoze Du. (2014) Optimal design of large scale dry cooling tower with consideration of off-design operation. Energy Procedia, 61, pp.190 - 193.

2. Xueping Du, Dongtai Han and Qiangmin Zhu. (2018) Heat Transfer Enhancement of the Air-Cooling Tower with Rotating Wind Deflectors under Crosswind Conditions. Appl. Sci., 8, pp.544.

3. ZhaoY B, Guoqing Long, Fengzhong Sun, Yan Li, Cuijiao Zhang. (2014) Numerical study on the cooling performance of dry cooling tower with vertical two-pass column radiators under crosswind. Applied Thermal Engineering, pp.1-12.

4. KB, Sai Sanjana, and Srikanth DV. "Thermal Analysis of Advanced IC Engine Cylinder." International Journal of Automobile Engineering Research and Development (IJAuERD) ISSN (P) (2016): 2277-4785.

5. Peixin Dong, Xiaoxiao Li, Kamel Hooman, Yubiao Sun, Jishun Li, Zhiqiang Guan, Hal Gurgenci. (2019)The crosswind effects on the start-up process of natural draft dry cooling towers in dispatchable power plants. Int. J. of Heat and Mass Transfer, 135, pp.950-961.

6. Kavitha, P., and N. Kishan. "Quasilinearization approach to mhd heat transfer to non-newtonian power-law fluids flowing over a wedge with heat source/sink in the presence of viscous dissipation." Int. J. Math. Comput. Appl. Res 3 (2013): 15-28.

7. Hemmasian Kashania M M and Dobrego K V. (2013)Heat and Mass Transfer In Natural Draft Cooling Towers. J. of Engg. Physics and Thermophysics, 86-5, pp.1072-1082.

8. Milman $O O$, Ptakhin A V, Kondratev A V, Shifrina B A and Yankov G G. (2016) Startup of Air-Cooled Condensers and Dry Cooling Towers at Low Temperatures of the Cooling Air. Thermal Engineering, 63-5, pp.329-335. 
9. SunJ, Yuan K, Yang L J. (2015) Distribution optimization of circulating water in air-cooled heat exchangers for a typical indirect dry cooling system on the basis of entransy dissipation. Science China Technological Sciences, 58-4, pp.617-629.

10. KB, Sai Sanjana, and Srikanth DV. "Thermal Analysis of Advanced IC Engine Cylinder." International Journal of Automobile Engineering Research and Development (IJAuERD) ISSN (P) (2016): 22774785.Kavitha, P., and N. Kishan. "Quasilinearization approach to mhd heat transfer to non-newtonian power-law fluids flowing over a wedge with heat source/sink in the presence of viscous dissipation." Int. J. Math. Comput. Appl. Res 3 (2013): 15-28.Qashqaei, Amir, and Ramin Ghasemi Asl. "Numerical Modeling And Simulation Of Copper Oxide Nanofluids Used In Compact Heat Exchangers." International Journal of Mechanical Engineering, 4 (2), 18 (2015).

11. Lei Chen, Lijun Yang, Xiaoze Du, Yongping Yang. (2016) Performance improvement of natural draft dry cooling system by interior and exterior windbreaker configurations. Int. J. of Heat and Mass Transfer, 96, pp.42-63.

12. Peixin Dong, Xiaoxiao Li, Zhiqiang Guan, Hal Gurgenci. (2018)The transient start-up process of natural draft dry cooling towers in dispatchable thermal power plants. Int. J. of Heat and Mass Transfer, 123, pp.201-212.

13. Tao Wu, Huimin Wei, Zhihua Ge, Lijun Yang, Xiaoze Du. (2019) Cooling water mass flow optimization for indirect dry cooling system of thermal power unit under variable output load. Int. J. of Heat and Mass Transfer, 133, pp.1-10.

14. Uma Maheswari C, Meenakshi Reddy R, Hemachandra Reddy K. (2017)Analysis of Design Parameters of Radiator. Research Journal of Pharmaceutical, Biological, and chemical sciences, 8-3, pp.35-44.

15. Nasrawi, Hayder Kraidi Rashid. "Natural Convection Heat Transfer inside an Inclined Square Enclosure Filled with Al2o3 Nanofluid in Presence of Pair of Discrete Heat Flux Sources in Bottom Wall." International Journal of Mechanical Engineering (IJME) 3.1 (2014): 35-46.

16. Keiji Oda, Yuichi Imasaka, Tomoya Yamauchi, Yoshihiro Nakane, Akira Endo \& Yasuhiro Yamaguchi. (2004) Deuterized Radiator for Detection of High-Energy Neutrons with Plastic Nuclear Track Detector. J. of Nuclear Sci. and Tech., 41-4, pp.514-517.

17. Akash A R, Abraham Satyanand, Pattamatta Arvind \& Das Sarit K. (2018) Experimental assessment of the thermo-hydraulic performance of automobile radiator with metallic and non-metallic nanofluids. Heat Transfer Engineering, 41:3, pp.235-251.

18. BarakatM A and Mahmoud M H H. (2000) Recovery of Metal Values from Car-Radiator Scrap. Separation Science and Technology, 35-14, pp.2359-2374.

19. Tapas Chakravarty \& Asok De FIETE. (1999) Investigation of Modes Tunable Circular Patch Radiator with Arbitrarily Located Shorting Posts. IETE Technical Review, 16-1, pp.109-111.

20. Jørgen Christiansen. (1981) Balancing radiator systems. Batiment International, Building Research and Practice, 9-3, pp.144144.

21. CullenA L. (1949) B.Sc. XXXVII. Channel section waveguide radiator. The London, Edinburgh, and Dublin Philosophical Magazine, and Journal of Science, 40-303, pp.417-428.

22. Yair Etzion and Evyatar Erell. (2011) Low-Cost Long-Wave Radiators for Passive Cooling of Buildings. Architectural Science Review, 42-2, pp. 79-85.

23. Zeinali Heris S, Shokrgozar M, Poorpharhang S, Shanbedi M and Noie S H. (2014) Experimental Study of Heat Transfer of a Car Radiator with CuO/Ethylene Glycol-Water as a Coolant. J. of Dispersion Science and Technology, 35-5, pp. 677-684. 
24. Jafar Mahmoudi. (2006) Modeling of Flow Field and Heat Transfer in a Copper-Base Automotive Radiator Application. International Journal of Green Energy, 3, pp.125-41.

25. Kyoung Woo Park and Hi Yong Pak. (2002) Flow and Heat Transfer Characteristics in Flat Tubes of a Radiator. Numerical Heat Transfer- Part A: Applications: An Int. J. of Computation and Methodology, 41, pp.119-40.

26. Gorman J M. (2015) Carideo M, Sparrow E M, Abraham J P, Heat transfer and pressure drop comparison of louver and plain finned heat exchangers where one fluid passes through flattened tubes. Case Studies in Thermal Engineering, 5, pp. 122-126.

\section{NOMENCLATURE}

\begin{tabular}{|c|}
\hline Air velocity $=V_{a}$ \\
\hline Number of transfer units $=$ NTU \\
\hline Air mass flow rate $=\mathrm{m}_{\mathrm{a}}$ \\
\hline Air specific heat $=\mathrm{Cp}_{\mathrm{a}}$ \\
\hline Base surface area $=A_{b}$ \\
\hline The coefficient for calculating efficiency $=\mathrm{m}$ \\
\hline Convective heat transfer coefficient of air $=\mathrm{h}_{\mathrm{a}}$ \\
\hline $\begin{array}{l}\text { Convective heat transfer coefficient of } \\
\text { water }=h_{w}\end{array}$ \\
\hline Corrected fin length $=\mathrm{L}_{\mathrm{c}}$ \\
\hline The density of water $=\rho_{\mathrm{w}}$ \\
\hline Dynamic viscosity of water $=\mu_{\mathrm{w}}$ \\
\hline Effectiveness $=\varepsilon$ \\
\hline Fin efficiency $=\eta_{\text {fin }}$ \\
\hline Fin length $=\mathrm{L}_{\mathrm{f}}$ \\
\hline Fin thickness $=\mathrm{H}_{\mathrm{f}}$ \\
\hline Fin width $=\mathrm{W}_{\mathrm{f}}$ \\
\hline Heat capacity ratio $=\mathrm{Cr}$ \\
\hline Heat transfer rate $=\mathrm{q}$ \\
\hline Inlet air temperature $=T_{a, \text { in }}$ \\
\hline Inlet water temperature $=\mathrm{T}_{\mathrm{w}, \text { in }}$ \\
\hline Kinematic viscosity of air $=v_{a}$ \\
\hline Maximum heat capacity $=\mathrm{C}_{\max }$ \\
\hline Maximum heat transfer rate $=\mathrm{q}_{\max }$ \\
\hline Minimum heat capacity $=\mathrm{C}_{\min }$ \\
\hline Number of tubes $=\mathrm{N}_{\mathrm{t}}$ \\
\hline Nusselt number of air $=\mathrm{Nu}_{\mathrm{a}}$ \\
\hline Nusselt number of water $=\mathrm{Nu}_{\mathrm{w}}$ \\
\hline Outlet air temperature $=\mathrm{T}_{\mathrm{a}, \text { out }}$ \\
\hline Outlet water temperature $=T_{w}$, out \\
\hline $\begin{array}{l}\text { Overall heat transfer coefficient }=\mathrm{UA} \\
\text { Overall surface efficiency }=\eta_{\mathrm{o}}\end{array}$ \\
\hline Prandtl number of air $=\operatorname{Pr}_{\mathrm{a}}$ \\
\hline Radiator length $=\mathrm{L}_{\mathrm{r}}$ \\
\hline Radiator width $=\mathrm{W}_{\mathrm{r}}$ \\
\hline Reynolds number of air $=\mathrm{Re}_{\mathrm{a}}$ \\
\hline Reynolds number of water $=\operatorname{Re}_{w}$ \\
\hline Single fin surface area $=A_{f}$ \\
\hline Thermal conductivity of air $=\mathrm{K}_{\mathrm{a}}$ \\
\hline Thermal conductivity of aluminum $=\mathrm{K}_{\mathrm{al}}$ \\
\hline Thermal conductivity of water $=\mathrm{K}_{\mathrm{w}}$ \\
\hline Total air heat capacity $=\mathrm{C}_{\mathrm{air}}$ \\
\hline Total external surface area $=A_{\text {external }}$ \\
\hline Total fin/base surface area of a single tube $=A_{\text {fin, base }}$ \\
\hline Total internal surface area $=\mathrm{A}_{\text {internal }}$ \\
\hline
\end{tabular}




\begin{tabular}{|l|}
\hline Total water heat capacity $=\mathrm{C}_{\mathrm{water}}$ \\
\hline Tube cross-sectional area $=\mathrm{A}_{\mathrm{t}}$ \\
\hline Tube height $=\mathrm{H}_{\mathrm{t}}$ \\
\hline Tube perimeter $=\mathrm{P}_{\mathrm{t}}$ \\
\hline Tube width $=\mathrm{W}_{\mathrm{t}}$ \\
\hline water mass flow rate $=\mathrm{m}_{\mathrm{w}}$ \\
\hline Water specific heat $=\mathrm{Cp}_{\mathrm{w}}$ \\
\hline Water velocity $=\mathrm{V}_{\mathrm{w}}$ \\
\hline
\end{tabular}


